\title{
The effects of various ceramic-metal on wear performance of clad layer
}

\author{
S.W. Wang, Y.C. Lin*, Y.Y. Tsai \\ Department of Mechanical Engineering, National Taiwan University of Science and Technology, Taipei, Taiwan, ROC
}

\begin{abstract}
This work deals with the wear performance of clad layers, which clad WC and TiC powders on medium carbon steel by gas tungsten arc welding (GTAW) method. Various metal powders with equal percentage by weight were added to the base powder (WC, TiC) to prepare the cladding materials, which were used to study the effects of various ceramic-metal cladding materials on clad surface wear resistance ability. A rotating type tribometer was used to evaluate the wear behaviors of different cladding specimens under dry sliding conditions. According to the experimental results, the specimen clad by WC-based powder contains certain Ti metal powders which had the best wear performance in all WC clad specimens. In all TiC cladding specimens, the TiC with $\mathrm{W}$ clad layer had superior wear performance to the other cladding specimens under low sliding speed condition. On the contrary, the $\mathrm{TiC}$ with $\mathrm{Cu}$ clad layer was superior to the other cladding specimens under high sliding speed condition. In addition, oxide films influence the wear behaviors of different specimens during wear testing, and at some conditions oxidation wear would dominate the wear behaviors of clad layer.
\end{abstract}

(C) 2003 Elsevier B.V. All rights reserved.

Keywords: Cladding; Wear resistance; Gas tungsten arc welding

\section{Introduction}

The ceramic materials are used numerously in surface cladding, especially in the fields of wear performance improvement of surface. They can improve wear and corrosion resistance of the mechanical elements without affecting the internal properties. In this way, the clad-substrate as a whole reaches a higher yield and a greater versatility in their application $[1,2]$.

In general, wear behaviors of materials can be markedly influenced by the presence of a second phase in the single-phase matrix, or by the use of a multiphase structure $[3,4]$. Reinforcing with a hard phase may be a good alternative to improve the wear resistance of a softer material without significantly changing other properties such as density. The improvement depends on material parameters such as properties of the reinforcing phase (size, geometry and hardness), properties of the matrix (hardness and ductility) and also properties of the bonding between reinforcing phase and matrix [5].

Beidi et al. [6] compared with the abrasive wear behaviors of cemented WC particles of the same size and ratio by atomic hydrogen welded coating (AHWC) and

\footnotetext{
* Corresponding author. Tel.: +886-2-2737-6498; fax: +886-2-2737-6460.

E-mail address: yclin@mail.ntust.edu.tw (Y.C. Lin).
}

laser-claded ceramic-metal coating (LCCC). The abrasive wear results showed that LCCC have superior wear resistance to AHWC. Zhenda et al. [7] used $3 \mathrm{~kW} \mathrm{CO}$ laser cladding of WC/Ni-based alloy powder on mild steel (AISI 1020) produced a high wear resistance composite coating with a strong metallurgical bond and minimal dilution, which consisted of hard WC particles and Ni-based alloy matrix. The wear resistance of this WC-Ni clad layer was superior to normal metal materials, which was attributed to the uniform distribution of hard WC particles embedded in a tough fine-dendritic Ni-based alloy matrix produced by the laser cladding process. Axen and Zum Gahr [8] studied the abrasive wear behavior of TiC clad layers. In this study, TiC-steel composite clad layers containing about $50 \mathrm{vol} . \%$ $\mathrm{TiC}$ of 3 or $30 \mu \mathrm{m}$ size were produced on the tool steel $90 \mathrm{MnCrV} 8$ using a $3.5 \mathrm{~kW} \mathrm{CO} 2$ laser. The results showed that the abrasive wear resistance was markedly influenced by the size of reinforcing $\mathrm{TiC}$ particles, matrix hardness, retained austenite and abrasive grit size. Lei et al. [9] studied a TiC-Ni alloy composite coating which was clad to 1045 steel substrate using a $2 \mathrm{~kW} \mathrm{CO}$ laser. The microstructural constituents of the clad layer are found to be $\gamma-\mathrm{Ni}$ and $\mathrm{TiC}$ in the dendrites, and a fine eutectic of $\gamma$-Ni plus $(\mathrm{Fe}, \mathrm{Cr})_{23} \mathrm{C}_{6}$ in the interdendritic areas. The TiC particles offer significantly enhanced wear resistance, the degree of wear depending primarily on the debonding removal of the particles. Wu [10] developed an in situ method to 
produce a $\mathrm{Ni}$ alloy composite coating. TiC dispersoid in a $\mathrm{Ni}$ alloy using one-step laser-clad coating on a $5 \mathrm{CrMnMo}$ steel substrate. In this process, dispersed and ultra-fine $\mathrm{TiC}$ particles were formed in situ in the coating. Most of the TiC particles with a marked gradient distribution, were uniformly distributed within interdendritic regions because of the trapping effect of the advanced solid-liquid interface. However, the influence of ceramic-metal powders clad layer on wear performance is still not fully understood.

Therefore, this work investigates the wear performance of ceramic-metal clad layers in which various ceramic-metal powders were clad on medium carbon steel by the gas tungsten arc welding (GTAW) method. The influence of hardness of the clad layer, microstructure, various compositions of cladding powder, applied load, and sliding speed were evaluated. Moreover, AISI 1050 base metal was used as the reference material whose properties were compared with the clad specimens.

\section{Experimental}

In this work, base powders (TiC, WC) and a specified metal powders $(\mathrm{Ni}, \mathrm{Cr}, \mathrm{Co}, \mathrm{Mo}, \mathrm{W}$, Ti or $\mathrm{Cu})$ were placed in a mixing-jar in the ratio of 10:1 by weight percent, shown in Table 1. During blending, steel balls were placed in the ball milling-jar to ensure that the powders were uniformly mixed. After blending for $24 \mathrm{~h}$, the composite powders were rolled into $80 \mathrm{~mm}$ long, $5 \mathrm{~mm}$ wide and $1 \mathrm{~mm}$ thick strip. Thereafter, the rolled strips were stuck to the surface of the AISI 1050 steel block, which had a dimension $100 \mathrm{~mm} \times 20 \mathrm{~mm} \times$ $25 \mathrm{~mm}$, using high-temperature silicone tape. The chemical composition of AISI 1050 carbon steel substrate is shown in Table 2. Finally, cladding was performed by GTAW method. The conditions of the cladding process are traveling speed $8 \mathrm{~cm} / \mathrm{min}$ and current $100 \mathrm{~A}$. After cladding pro-

Table 1

Composition of various cladding powders $(\mathrm{g})$

\begin{tabular}{|c|c|c|c|c|c|c|c|c|c|}
\hline \multirow{2}{*}{$\begin{array}{l}\text { Clad } \\
\text { layer }\end{array}$} & \multicolumn{2}{|c|}{ Ceramic powder } & \multicolumn{7}{|c|}{ Metal powder } \\
\hline & WC & $\mathrm{TiC}$ & $\mathrm{Ti}$ & $\mathrm{Ni}$ & $\mathrm{Cr}$ & Co & Mo & $\mathrm{W}$ & $\mathrm{Cu}$ \\
\hline WC-Ti & 10 & 0 & 1 & 0 & 0 & 0 & 0 & 0 & 0 \\
\hline $\mathrm{WC}-\mathrm{Ni}$ & 10 & 0 & 0 & 1 & 0 & 0 & 0 & 0 & 0 \\
\hline $\mathrm{WC}-\mathrm{Cr}$ & 10 & 0 & 0 & 0 & 1 & 0 & 0 & 0 & 0 \\
\hline $\mathrm{WC}-\mathrm{Co}$ & 10 & 0 & 0 & 0 & 0 & 1 & 0 & 0 & 0 \\
\hline WC-Mo & 10 & 0 & 0 & 0 & 0 & 0 & 1 & 0 & 0 \\
\hline WC-W & 10 & 0 & 0 & 0 & 0 & 0 & 0 & 1 & 0 \\
\hline $\mathrm{WC}-\mathrm{Cu}$ & 10 & 0 & 0 & 0 & 0 & 0 & 0 & 0 & 1 \\
\hline $\mathrm{TiC}-\mathrm{Ti}$ & 0 & 10 & 1 & 0 & 0 & 0 & 0 & 0 & 0 \\
\hline $\mathrm{TiC}-\mathrm{Ni}$ & 0 & 10 & 0 & 1 & 0 & 0 & 0 & 0 & 0 \\
\hline $\mathrm{TiC}-\mathrm{Cr}$ & 0 & 10 & 0 & 0 & 1 & 0 & 0 & 0 & 0 \\
\hline $\mathrm{TiC}-\mathrm{Co}$ & 0 & 10 & 0 & 0 & 0 & 1 & 0 & 0 & 0 \\
\hline TiC-Mo & 0 & 10 & 0 & 0 & 0 & 0 & 1 & 0 & 0 \\
\hline TiC-W & 0 & 10 & 0 & 0 & 0 & 0 & 0 & 1 & 0 \\
\hline $\mathrm{TiC}-\mathrm{Cu}$ & 0 & 10 & 0 & 0 & 0 & 0 & 0 & 0 & 1 \\
\hline
\end{tabular}

Table 2

Composition of the AISI 1050 substrate

\begin{tabular}{ll}
\hline Element & Composition (wt.\%) \\
\hline $\mathrm{C}$ & 0.51 \\
$\mathrm{Si}$ & 0.22 \\
$\mathrm{Mn}$ & 0.79 \\
$\mathrm{P}$ & 0.01 \\
$\mathrm{~S}$ & 0.009 \\
$\mathrm{Cr}$ & 0.15 \\
$\mathrm{Fe}$ & 98.3 \\
\hline
\end{tabular}
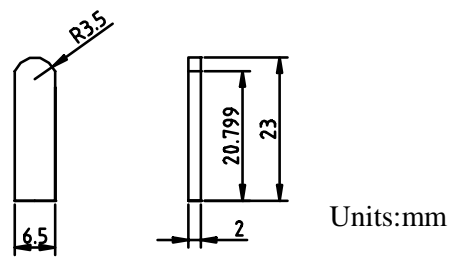

Fig. 1. Dimensions of moving upper specimen (clad specimen).

cess, the wire EDM machine is used to cut out the necessary specimens. Dimensions of clad specimen are shown in Fig. 1.

A pin-on-disc rotating type tribometer was used to evaluate the wear resistance ability. A moving upper specimen (pin) and a fixed lower specimen (disk) were mounted at the ends of a driven shaft and a fixed shaft, respectively. During wear testing, PC associated with data acquisition system monitored and recorded the frictional and normal forces continuously.

The disc counter specimen was made of hardened AISI 52100 bearing steel, which is used as a standard counter specimen for wear performance evaluation. The hardness of the hardened AISI 52100 bearing steel was kept about HRc 63. In order to evaluate the wear resistance ability of these specimens, the wear test was conducted under certain conditions, as shown in Table 3. Before wear testing, the rubbed surface of the disk specimen was polished by $\mathrm{SiC}$ abrasive papers up to 600 grits and had a surface roughness $R_{\mathrm{a}}=0.2 \mu \mathrm{m}$. Moreover, the set of wear testing specimens was cleaned ultrasonically in acetone for $30 \mathrm{~min}$. After wear test, the worn surface and the microstructure of cross-section of the specimens were analyzed by scanning electron microscope (SEM). Additionally, EPMA was used to identify the compositions of compound and inclusions in the clad layer. Finally, the worn loss of volume was used to evaluate the wear resistance ability of each specimen.

Table 3

Wear test conditions

Sliding speed $(\mathrm{m} / \mathrm{s})$

Load $(\mathrm{kg})$

Temperature, $T\left({ }^{\circ} \mathrm{C}\right)$

Lubrication condition

$0.79 / 2.36$

1.5/3.0/4.5

Room temperature

Dry 


\section{Results and discussion}

\subsection{Hardness of clad layers}

It is commonly accepted that hardness of a material is one of the most important factors, which influence wear performance of the material. Generally, increasing the hardness of components can enhance the wear resistance ability although the effect of hardness is not straightforward [11]. In this work, hardness of clad surface was measured using a microhardness indenter. The results show that hardness of various clad surface was enhanced obviously. The high hardness of clad layer results from the alloy element diffused to the matrix and the very quickly cooling rate, to enhance martensitic phase transformation during clad process, as well as second phase reinforcement. Moreover, the fast solidification of melted zone that resulted in $\mathrm{TiC}$ particles could not be molten fully due to its poor heat conductivity and high melting point. Therefore, TiC particles in the metal matrix are either separated or connected to form a cluster. The phenomenon of connections among TiC particles may result from the moving interface between solid and liquid and the expulsion of non-dissolvable $\mathrm{TiC}$ particles to form a cluster during solidification. Therefore, these TiC particles were trapped in the final solidification region, causing them to connect to each other. This result is consistent with other research [10]. To observe the microstructure of TiC clad layer, it can be distinguished into $\mathrm{TiC}$ particles accumulation zone (TiC-AZ) and zone of TiC particles uniform distribution (TiC-UD). In the zone of TiC particles accumulation, the hardness could be up to $1800 \mathrm{Hv}$ and is higher than that of the zone of TiC-UD whose hardness was about $1000 \mathrm{Hv}$, as shown in Fig. 2.

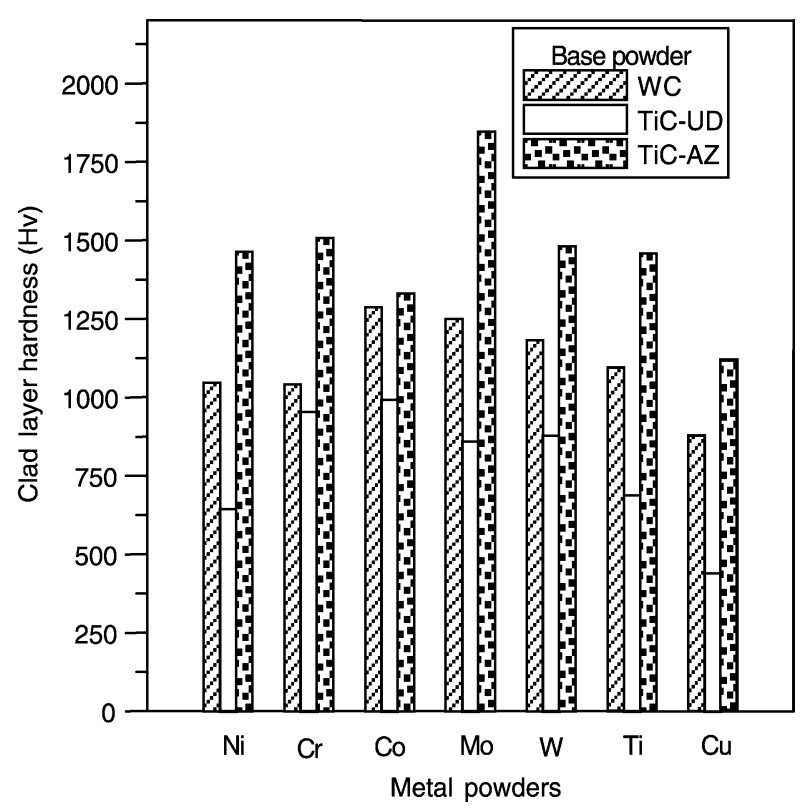

Fig. 2. Hardness of various clad layers.
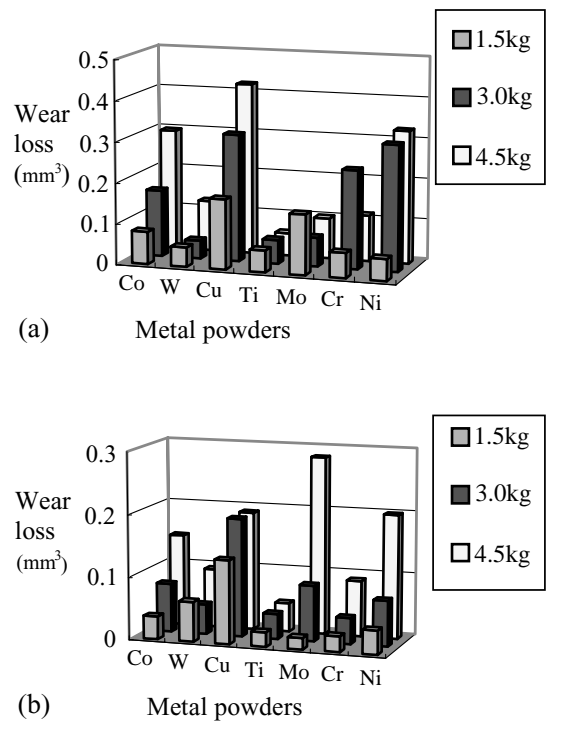

Fig. 3. Wear loss of various WC clad layers after a sliding distance $1413.72 \mathrm{~m}$ : (a) sliding speed $=0.79 \mathrm{~m} / \mathrm{s}$; (b) sliding speed $=2.36 \mathrm{~m} / \mathrm{s}$.

In all WC clad layer specimens, WC-Mo and WC-Co clad layer had higher hardness (up to $1250 \mathrm{Hv}$ ) than the other WC clad layers. On the contrary, hardness of WC-Cu clad layer was the lowest. Also, Fig. 2 reveals that hardness of clad layers was affected by the alloy elements. In general, the hardness of the top of clad layer is higher than that of the zone near the substrate.

\subsection{Wear performance of WC clad layer}

Fig. 3 shows the wear loss of all WC clad specimens with different cladding powders under different wear test condition after sliding $1413.72 \mathrm{~m}$. At $0.79 \mathrm{~m} / \mathrm{s}$ sliding speed condition, the wear loss of WC clad layer with different loading are shown in Fig. 3(a). It can be seen that at a light loading $(1.5 \mathrm{~kg})$ condition, the wear performances of the WC-W, WC-Ti, and W-Ni clad layers were better than that of the other clad layers. With applied load increasing, the wear loss of $\mathrm{WC}-\mathrm{W}, \mathrm{WC}-\mathrm{Co}, \mathrm{WC}-\mathrm{Cu}, \mathrm{WC}-\mathrm{Cr}$, and $\mathrm{WC}-\mathrm{Ni}$ clad layers increase, but a slight reduction in wear loss can be observed on the WC-Ti, WC-Mo, and WC-Cr clad layers. Similarly, at the sliding speed $(2.36 \mathrm{~m} / \mathrm{s})$ test condition, the wear loss of WC-Co, WC-Mo, WC-Cr, and $\mathrm{WC}-\mathrm{Ni}$ clad specimens also increased with the load, as shown in Fig. 3(b). Moreover, at $1.5 \mathrm{~kg}$ loading condition, the clad layers of WC-Ti, WC-Mo, and WC-Cr had a superior wear performance to the other clad specimens.

It is of interest to note that the hardness of the $\mathrm{WC}-\mathrm{Co}$ clad layer is higher than that of the other WC clad layers, but the wear performance of WC-Co clad layer was not the best one in all WC clad layers. In all WC cladding specimens, although WC-Ti clad layer was not the hardest, it had the best wear performance than the others. This result reveals 
that the wear-resistant ability of clad layer is not always dominated by hardness.

Moreover, at 0.79 sliding speed conditions, variation of wear loss of WC-Ti clad layer with applied load was unobvious. To monitor this wear test process, some black fine powders could be observed between the rubbing surfaces during rubbing process. The phenomenon indicates that oxide films are being developed on the rubbing surfaces to change wear mechanism into oxidation wear and avoid adhesive wear and reduce abrasive wear [12].

EPMA result of WC-Mo clad layer is shown in Fig. 4. From Fig. 4(a) it can be identified that the reinforcement of second phase in WC-Mo is the precipitate of tungsten. Moreover, EPMA lines scan clearly displays that reinforcement (second phase) consists of $\mathrm{W}$ and $\mathrm{C}$ elements. It is embedded in the clad layer, and also implies that the distribution of reinforcement phase in the clad layer can cause precipitates strengthening. This is the main reason for the excellent wear performance of the WC clad layer [7].

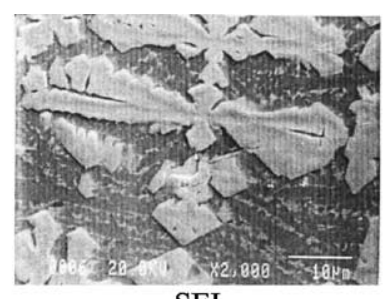
SEI

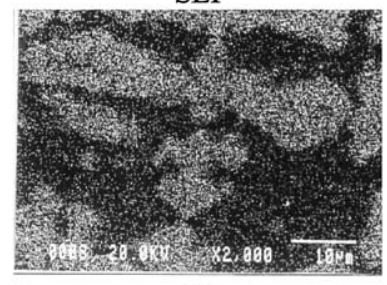

W
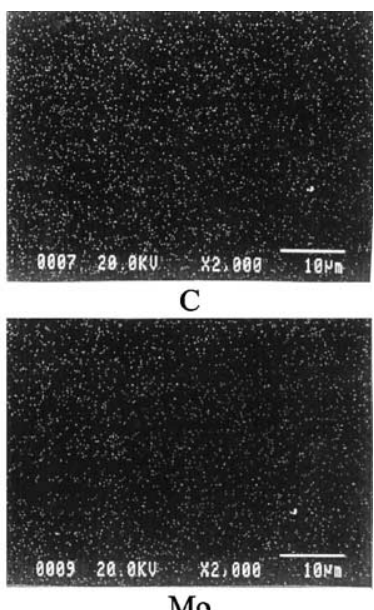

(a)

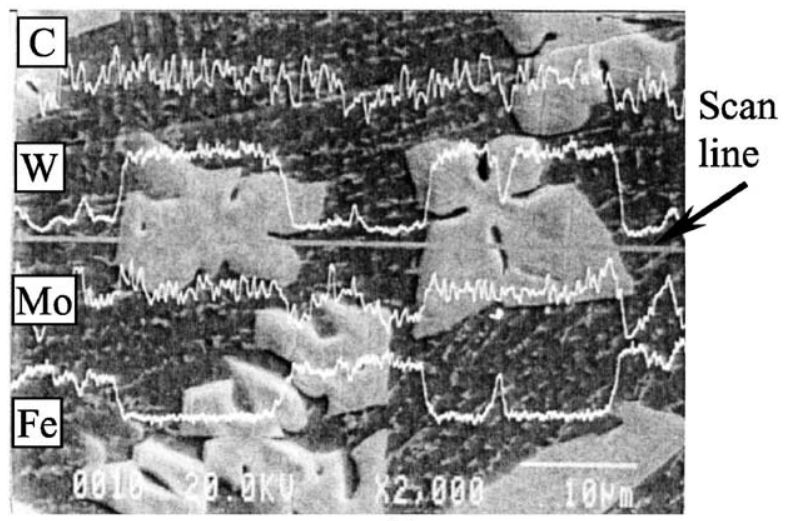

(b)

Fig. 4. EPMA analysis of WC-Mo clad layer: (a) microstructure morphology of clad surface and various element mapping; (b) line scanning of the clad layer (etched by $3 \mathrm{~g} \mathrm{~K}_{3} \mathrm{FeCN}_{6}+1 \mathrm{~g} \mathrm{NaOH}+100 \mathrm{ml} \mathrm{H}_{2} \mathrm{O}$ for $5 \mathrm{~s}$ ).
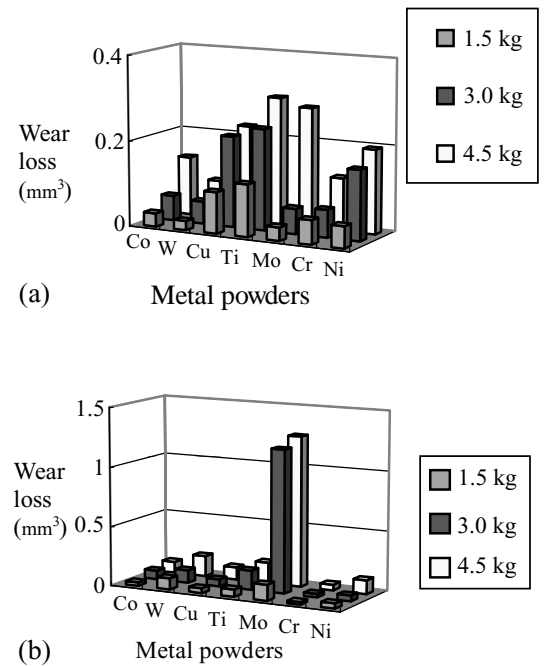

Fig. 5. Wear loss of TiC base powder with various metal powders clad specimens after a sliding distance $1413.72 \mathrm{~m}$ : (a) sliding speed $=0.79 \mathrm{~m} / \mathrm{s}$; (b) sliding speed $=2.36 \mathrm{~m} / \mathrm{s}$.

\subsection{Wear behavior of TiC clad layer}

Fig. 5 shows the wear loss of all TiC clad specimens with different cladding powders under various test conditions after sliding $1413.72 \mathrm{~m}$. At the sliding speed of $0.79 \mathrm{~m} / \mathrm{s}$ and applied load of $1.5 \mathrm{~kg}$, the wear loss of TiC-W clad layer is lower than the other clad specimens, as shown in Fig. 5(a). When loading is increased up to $3.0 \mathrm{~kg}$, the wear loss of TiC-Co, TiC-W, TiC-Mo, and TiC-Cr clad specimens are less than that of $\mathrm{TiC}-\mathrm{Cu}, \mathrm{TiC}-\mathrm{Ti}$, and $\mathrm{TiC}-\mathrm{Ni}$ clad specimens. At the highest loading of $4.5 \mathrm{~kg}$, the wear loss of TiC-W clad specimen is still lower than the other clad specimens. From the above results, it can be seen that $\mathrm{TiC}-\mathrm{W}$ clad layer has an excellent wear resistance performance at low sliding speed $(0.79 \mathrm{~m} / \mathrm{s})$.

At the sliding speed of $2.36 \mathrm{~m} / \mathrm{s}$, the wear loss of $\mathrm{TiC}-\mathrm{Cr}$ clad specimen is lower than that of the other clad specimens, as shown in Fig. 5(b). From Fig. 5(b), it is clear that the influence of applied load on the wear loss of $\mathrm{TiC}-\mathrm{Cr}$ clad layer is unobvious. It seems reasonable to conclude that $\mathrm{TiC}-\mathrm{Cr}$ clad specimens have excellent wear performance at the sliding speed of $2.36 \mathrm{~m} / \mathrm{s}$.

EPMA results of TiC-Cr clad layer are shown in Fig. 6. The EPMA results can identify that the reinforcement is the residual particles of $\mathrm{TiC}$, which were not dissolved during cladding process. The fast solidification of melted zone, poor heat conductivity and high melting point of $\mathrm{TiC}$ particles caused this result. Furthermore, the low conductivity and high thermal expansion of $\mathrm{TiC}$ also induce the high thermal stress in $\mathrm{TiC}$ particles, sometimes splitting them, as shown in Fig. 6(b). This splitting provides an initial crack and causes crack propagation during loading that reduces the strength of the clad layer in applications. However, the uniform distribution residual particles of $\mathrm{TiC}$ can enhance the clad layer strength by dispersion strengthening [13]. 


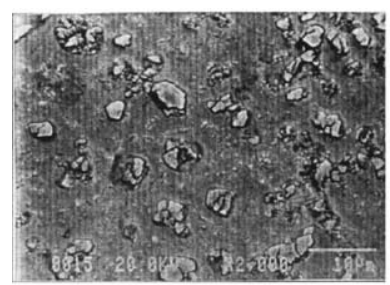

SEI

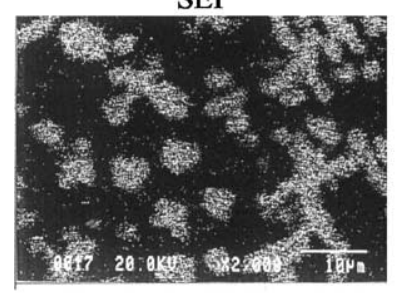

$\mathrm{Ti}$

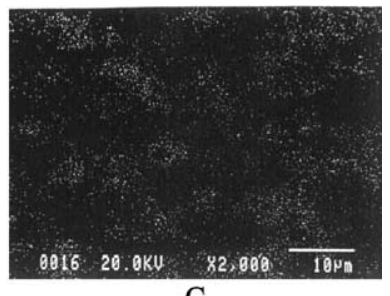

$\mathrm{C}$

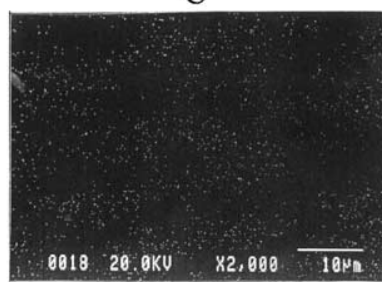

Mo (a)

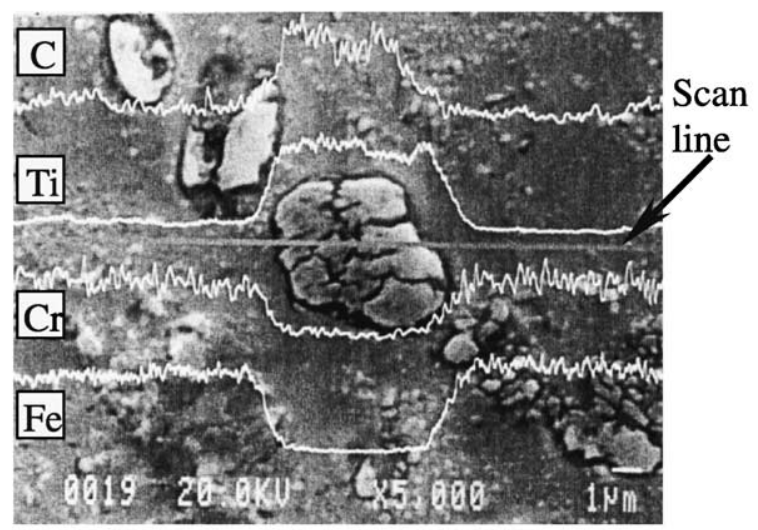

(b)

Fig. 6. EPMA analysis of $\mathrm{TiC}$ base powder with $\mathrm{Cr}$ clad layer: (a) clad surface morphology and various element mapping; (b) line scanning of the clad layer. (etched using $3 \mathrm{~g} \mathrm{~K}_{3} \mathrm{FeCN}_{6}+1 \mathrm{~g} \mathrm{NaOH}+100 \mathrm{ml} \mathrm{H}_{2} \mathrm{O}$ for $5 \mathrm{~s})$.

\subsection{Effect of sliding speed on wear behavior and morphology of the worn surface}

Figs. 7 and 8 show the morphology of worn surface of WC-Mo and TiC-Mo clad layers after wear test under sliding speed of $2.36 \mathrm{~m} / \mathrm{s}$ and load of $1.5 \mathrm{~kg}$. In Fig. 7, the morphology of worn surface indicates the presence of cracks, cavities and oxide film (the dark area on the figure). This oxide film is believed to cause the wear loss of some WC clad layer to decrease with increasing sliding speed. This reveals that oxide film formation usually has some benefits during rubbing process without lubricant. But at the highest load of $4.5 \mathrm{~kg}$ and sliding speed of $2.36 \mathrm{~m} / \mathrm{s}$, the wear loss of WC-Mo clad layer increases with increasing sliding speed. This result may be caused by the strength of WC-Mo weakened and could not support the oxide in well situation at high loading and sliding condition (rubbing temperature is high in this state). On the contrary, the wear loss of WC-W and WC-Ti clad layers are not affected by the sliding speeds.

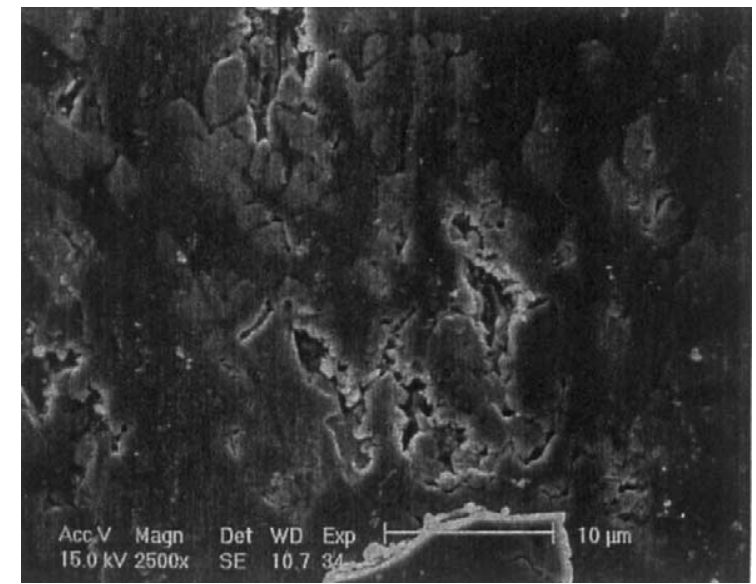

Fig. 7. Worn surface morphology of WC base powder with Mo clad layer, wear test conditions: sliding speed $=2.36 \mathrm{~m} / \mathrm{s}$; load $=1.5 \mathrm{~kg}$; sliding distance $=1413.72 \mathrm{~m}$

This result shows that these clad layers have a good strength of high temperature and oxide film could be established on rubbing surface to lubricate the rubbing interface between the sliding bodies.

Similarly, sliding speed also affects the wear loss of TiC clad specimens obviously. At the sliding speed of $2.36 \mathrm{~m} / \mathrm{s}$, the wear loss of TiC-Mo clad specimen increases quickly with increasing applied load. This result may be caused by the high sliding speed raising the temperature at rubbing surface and result in matrix softening. Consequently, the matrix could not support the reinforcement well and wear loss increasing. The worn surface morphology of TiC-Mo clad layer is shown in Fig. 8. It can be seen that plastic flows on the worn surfaces clearly.

From the above results of wear tests and worn surface analyses, they could be concluded that sliding speed affects wear behavior more than other factors such as applied load. The temperature of rubbing surface increases with increasing sliding speed which results in (1) change in the formation

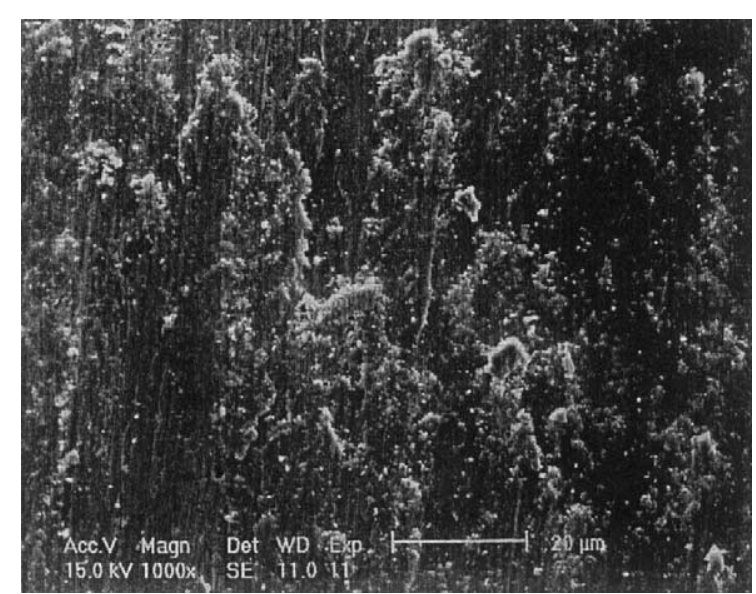

Fig. 8. Worn surface morphology of TiC-Mo clad layer, wear test conditions: sliding speed $=2.36 \mathrm{~m} / \mathrm{s} ;$ load $=1.5 \mathrm{~kg} ;$ sliding distance $=$ $1413.72 \mathrm{~m}$. 
rate of oxide films on rubbing surface and (2) matrix softening to reduce clad layer strength.

\section{Conclusions}

From the experimental results obtained in this work, the following conclusions can be drawn:

(1) WC-Ti clad layer has excellent wear performance.

(2) For TiC and WC surface cladding, alloy elements can affect the hardness and wear performance of clad layer obviously.

(3) Oxide films being developed on the rubbing surface that markedly influences the wear behaviors of clad layer during unlubricated condition.

\section{Acknowledgements}

The authors would like to thank the National Science Council of the Republic of China, Taiwan, for financially supporting this research under Contract no. NSC 91-2212-E-011-031.

\section{References}

[1] D.E. Wolfe, J. Singh, J. Senderson, J. Zabinski, Laser-clad composite coatings, Adv. Mater. Process. 158 (2) (2000) 41-44.
[2] J. Mateos, J.M. Cuetos, E. Fernandez, R. Vijande, Tribological behavior of plasma-sprayed WC coatings with and without laser remelting, Wear 239 (2000) 274-281.

[3] K.-H. Zum Gahr, Microstructure and Wear of Materials, Elsevier, Amsterdam, 1987.

[4] W. Simm, S. Freti, Abrasive wear of multiphase materials, Wear 129 (1989) $105-121$.

[5] N. Axen, A. Alahelisten, S. Jacobson, Abrasive wear of alumina fibre-reinforced aluminium, Wear 173 (1994) 95-104.

[6] Z. Beidi, Z. Xiaoyan, T. Zengyi, Y. Shuguo, C. Kun, Coarse cemented WC particle ceramic-metal composite coatings produced by laser cladding, Wear 170 (1993) 161-166.

[7] C. Zhenda, L.L. Chew, Q. Ming, Laser cladding of WC-Ni composite, J. Mater. Process. Technol. 62 (1996) 321-323.

[8] N. Axen, K.-H. Zum Gahr, Abrasive wear of TiC-steel composite clad layers on tool steel, Wear 157 (1992) 189-201.

[9] T.C. Lei, J.H. Ouyang, Y.T. Pei, Y. Zhou, Microstructure and wear resistance of laser clad TiC particle reinforced coating, Mater. Sci. Technol. 11 (1995) 520-525.

[10] X. Wu, In situ formation by laser cladding of a TiC composite coating with a gradient distribution, Surf. Coat. Technol. 115 (1999) $111-115$.

[11] X.Y. Li, K.N. Tandon, Effect of ion implantation on the dry sliding wear behavior of $\mathrm{SiC}$ reinforced Al-Si composite, Surf. Coat. Technol. 90 (1997) 136-142.

[12] M. Vardavoulias, The role of hard second phases in the mild oxidational wear mechanism of high-speed steel-based materials, Wear 173 (1994) 105-114.

[13] Y.C. Lin, S.W. Wang, Wear behavior of ceramic powder cladding on an S50C steel surface, Tribol. Int. 36 (2003) 1-9. 